\title{
ARTIKELEN
}

\section{De Europese grenzen aan winstuitkering door zorgaanbieders}

\author{
Dr. L.R. Glas LLM, prof. mr. J.W. van de Gronden $\mathcal{E}$ mr. dr. J.M. Veenbrink*
}

\section{Inleiding}

Winstuitkering in de zorg is een controversieel onderwerp in de Nederlandse politiek en is in de huidige regelgeving aan banden gelegd. In juli 2019 informeerden de VWS-bewindspersonen de Tweede Kamer op basis van verricht ${ }^{1}$ onderzoek over hun plannen voor winstuitkering door zorginstellingen. ${ }^{2} \mathrm{Zij}$ zien 'geen noodzaak' om de mogelijkheden tot dergelijke winstuitkering uit te breiden, omdat er een 'beperkte behoefte' is aan risicodragend kapitaal en vanwege de risico's die dit met zich meebrengt, 'met name als de kwaliteit van zorg onvoldoende inzichtelijk is'. ${ }^{3}$ De bewindspersonen maken daarom 'een pas op de plaats' en willen eerst meer inzicht in de kwaliteit van de zorg en zijn voornemens om maatregelen te nemen zodat 'geld dat bedoeld is voor de zorg ook daadwerkelijk ten goede komt aan de zorg'.

Doordat de bewindspersonen geen definitief standpunt hebben ingenomen, mag verwacht worden dat winstuitkering in de zorg voer voor politieke discussie zal blijven. Bovendien zal de zorg en daarmee winstuitkering waarschijnlijk een belangrijk onderwerp worden van de verkiezingen in 2021 gezien de stijgende zorgkosten. ${ }^{5}$ Door de huidige coronacrisis zullen deze kosten verder stijgen. ${ }^{6}$ Daar komt nog bij dat de bewindspersonen wellicht met nieuwe plannen op het gebied van winstuitkering door zorginstellingen komen zodra er meer inzicht is in de kwaliteit van de zorg.

* Lize Glas is universitair docent Europees Recht bij de Radboud Universiteit, Nijmegen. Johan van de Gronden is hoogleraar Europees Recht bij de Radboud Universiteit, Nijmegen. Marc Veenbrink is universitair docent Europees Recht bij de Radboud Universiteit, Nijmegen.

1 De auteurs van dit artikel hebben het onderzoek verricht voor een van de twee rapporten die in het kader van dit onderzoek zijn opgeleverd. De focus van dit rapport is op de houdbaarheid vanuit Europees rechtelijk perspectief van het beperken of verbieden van winstuitkering door zorgaanbieders binnen het huidige stelsel. Het onderhavige artikel is mede op dit rapport gebaseerd. Beide rapporten kunnen worden geraadpleegd op de volgende site: www.tweedekamer.nl/kamerstukken/detail?id=2019Z14882\&did=2019D30514.

2 Brief van de Minister van Volksgezondheid, Welzijn en Sport en de Minister voor Medische Zorg en Sport en de Staatssecretaris van Volksgezondheid, Welzijn en Sport, Kamerstukken I 2018/19, 33168, O.

3 Brief van de Minister van Volksgezondheid, Welzijn en Sport en de Minister voor Medische Zorg en Sport en de Staatssecretaris van Volksgezondheid, Welzijn en Sport, Kamerstukken I 2018/19, 33168, O, p. 2, 3.

4 Brief van de Minister van Volksgezondheid, Welzijn en Sport en de Minister voor Medische Zorg en Sport en de Staatssecretaris van Volksgezondheid, Welzijn en Sport, Kamerstukken I 2018/19, 33168, O, p. 3, 4.

5 CBS, 'Zorguitgaven stijgen in 2018 met 3,1 procent', 21 juni 2019, www.cbs.nl/nl-nl/nieuws/2019/25/ zorguitgaven-stijgen-in-2018-met-3-1-procent.

6 Vergelijk bijvoorbeeld de Brief van de Minister van Volksgezondheid, Welzijn en Sport, Kamerstukken II 2019/20, 25295, nr. 351, p. 34. 
Aangezien winstuitkering door zorgaanbieders de politieke agenda zal blijven beheersen, is het nuttig om helderheid te scheppen over het juridisch kader waarmee rekening gehouden dient te worden wanneer dergelijke winstuitkering wordt gereguleerd in het Nederlandse zorgstelsel dat op marktwerking is gebaseerd. Dit roept vragen op vanuit het perspectief van het EU-recht voor de interne markt en het fundamentele recht op eigendom. Dit artikel gaat daarom na welke ruimte het Europees Verdrag voor de Rechten van de Mens (EVRM) en het Unierecht laten om politieke compromissen te sluiten op het gebied van winstuitkering door zorgaanbieders. Met andere woorden: welke randvoorwaarden gelden er op basis van het EVRM en het Unierecht om winstuitkering in (bepaalde sectoren van) de zorg te reguleren? Onder regulering wordt in dit verband verstaan zowel het verbieden van winstuitkering als het verbinden van bepaalde voorwaarden en beperkingen aan een dergelijke uitkering. In het navolgende wordt eerst ingegaan op de relevante wettelijke en politieke context. Daarna komt winstregulering in het licht van het EVRM aan de orde. Vervolgens wordt deze problematiek bezien vanuit het perspectief van het EU-recht. Afgesloten wordt met enige conclusies.

\section{De wettelijke en politieke context}

In het huidige Nederlandse zorgstelsel, dat gebaseerd is op marktwerking, wordt door de wetgever ervan uitgegaan dat zorgaanbieders concurreren. ${ }^{7}$ Dit heeft er echter nog niet toe geleid dat het aan alle zorgaanbieders is toegelaten om de op de markt verworven winst uit te keren aan investeerders en aandeelhouders. Onder het huidige Nederlandse zorgregime geldt zelfs het uitgangspunt dat zorgaanbieders geen winst mogen uitkeren. Dit is het gevolg van de Wet toelating zorginstellingen (WTZi). Deze wet verleent in beginsel geen toelating tot de zorgmarkt aan instellingen met een winstoogmerk. ${ }^{8}$ Hierop zijn uitzonderingen aangebracht per besluit. ${ }^{9}$ Deze uitzonderingen komen erop neer dat zorgaanbieders die extramurale zorg aanbieden wel winst mogen uitkeren. ${ }^{10}$ Bovendien behoeft een drietal categorieën zorgaanbieders geen toelating op basis van de WTZi. Het gaat dan allereerst om derde partijen of dochterondernemingen die namens een toegelaten zorg-

$7 \quad$ Zie Kamerstukken II 2003/04, 29763, nr. 3, p. 18.

8 Art. 5(1) WTZi. Het gaat dan om zorgaanbieders die zorg willen aanbieden die vergoed wordt door (1) een zorgverzekeraar; of (2) vanuit de Wet langdurige zorg. Wanneer de geleverde zorg valt onder de Jeugdwet of de WMO is dus geen WTZi-toelating nodig. De Wet van 10 juni 2020 tot wijziging van diverse wetten in verband met de invoering van de Wet toetreding zorgaanbieders (Aanpassingswet Wet toetreding zorgaanbieders), (Stb. 2020, 181), zal art. 5 WTZi aanpassen. Dit artikel komt dan te luiden: 'Een instelling heeft geen winstoogmerk, behoudens de bij algemene maatregel van bestuur aan te wijzen categorieën van instellingen.' De definitie uit art. 5 lid 1 WTZi zal verplaatst worden naar art. 1(1)(f) WTZi.

9 Zie art. 3.1 Besluit van 3 november 2005, houdende uitvoering van enige bepalingen van de Wet toelating zorginstellingen (Uitvoeringsbesluit WTZi).

10 Op grond van de Zorgverzekeringswet en de Wet langdurige zorg. 
instelling (een deel van) de zorg verzorgen. ${ }^{11}$ Ten tweede behoeven solistische beroepsbeoefenaars niet over een toelating te beschikken. ${ }^{12}$ Tot slot is de toelatingseis niet van toepassing op logeeropvang met persoonsgebonden budget (pgb) in de Wet langdurige zorg. Instellingen die uitsluitend logeeropvang aanbieden aan pgb-houders hebben daarom geen WTZi-toelating nodig. ${ }^{13}$

Ondanks het uitgangspunt van marktwerking is winstuitkering nu in beginsel verboden, omdat de wetgever wil voorkomen dat publieke middelen door middel van winstuitkering wegvloeien naar private partijen - wat uiteindelijk kan leiden tot een verhoging van de zorgpremies. ${ }^{14}$ Daarnaast is de wetgever bevreesd dat winstuitkering tot onwenselijke productieprikkels leidt die mogelijk de kwaliteit en de betaalbaarheid van de zorg aantasten. ${ }^{15}$ Verder bestaan er volgens de wetgever gebreken in de marktwerking, waardoor de uitruil tussen kwaliteit en winst niet goed wordt bewaakt. ${ }^{16}$ Overigens kan gereguleerde winstuitkering ook voordelen hebben, zo leggen de bewindspersonen van het Ministerie van Volksgezondheid, Welzijn en Sport (VWS) uit. Dergelijke winstuitkering kan onder andere de doelmatigheid verbeteren omdat zij kostenbesparing stimuleert. ${ }^{17}$ Ook kan winstuitkering het makkelijker maken om financiering aan te trekken, waardoor investeringen in de kwaliteit, innovatie of continuiteit mogelijk zijn. ${ }^{18}$ Het wordt dan ook aantrekkelijker voor nieuwe toetreders om de markt te betreden, waardoor meer dynamiek ontstaat. ${ }^{19}$

11 Art. 6.4 lid 1 Uitvoeringsbesluit WTZi biedt impliciet de basis voor deze constructie door aan te geven dat er van andere organisatorische verbanden gebruik gemaakt mag worden zolang dit schriftelijk en inzichtelijk is vastgelegd. Bovendien erkent de doorlopende integrale toelichting bij de Wet kwaliteit, klachten en geschillen zorg (Wkkgz) expliciet de optie om zorg uit te besteden, zie Kamerstukken I 2013/14, 32402, F, p. 17. Zie verder antwoord van minister Schippers (VWS) (ontvangen 9 november 2016), Aanhangsel van de Handelingen Kamerstukken II 2016/17, nr. 449.

12 Omdat de toelatingseis alleen geldt voor 'instellingen' en de WTZi instellingen definieert als een 'organisatorisch verband' dat onvermijdelijk bestaat uit meer dan één beroepsbeoefenaar, zie art. 1 lid f juncto art. 5 lid 1 WTZi.

13 Zie Aanhangsel van de Handelingen, Kamerstukken II 2016/17, nr. 1976; memorie van toelichting bij Wijziging van de Wet langdurige zorg, de Wet maatschappelijke ondersteuning 2015, de Jeugdwet en de Zorgverzekeringswet, Kamerstukken II 2015/16, 34279, nr. 3, par. 3.4.

14 Memorie van toelichting bij de Herziening van het stelsel van overheidsbemoeienis met het aanbod van zorginstellingen (Wet exploitatie zorginstellingen), Kamerstukken II 2000/01, 27659, nr. 3, par. 4.3.2.

15 Memorie van toelichting bij de Herziening van het stelsel van overheidsbemoeienis met het aanbod van zorginstellingen (Wet exploitatie zorginstellingen), Kamerstukken II 2000/01, 27659, nr. 3, par. 4.3.2. Zie ook Vaststelling van de begrotingsstaten van het Ministerie van Volksgezondheid, Welzijn en Sport (XVI) voor het jaar 2018, brief van de Minister van Volksgezondheid, Welzijn en Sport, Kamerstukken II 2017/18, 34775XVI nr. 149, p. 2.

16 Memorie van toelichting bij de Herziening van het stelsel van overheidsbemoeienis met het aanbod van zorginstellingen (Wet exploitatie zorginstellingen), Kamerstukken II 2000/01, 27659, nr. 3, par. 4.3.2.

17 Vaststelling van de begrotingsstaten van het Ministerie van Volksgezondheid, Welzijn en Sport (XVI) voor het jaar 2018, brief van de Minister van Volksgezondheid, Welzijn en Sport, Kamerstukken II 2017/18, 34775 XVI, nr. 149, p. 2.

18 Vaststelling van de begrotingsstaten van het Ministerie van Volksgezondheid, Welzijn en Sport (XVI) voor het jaar 2018, brief van de Minister van Volksgezondheid, Welzijn en Sport, Kamerstukken II 2017/18, 34775XVI, nr. 149, p. 2.

19 Memorie van toelichting bij de Wet cliëntenrechten zorg en enkele andere wetten, Kamerstukken II 2011/12, 33168, nr. 3, p. 3. 
Over winstuitkering door zorgaanbieders kan dus verschillend worden gedacht. Het zal daarom geen verbazing wekken dat dit onderwerp binnen de huidige coalitie een heet politiek hangijzer is. ${ }^{20}$ Terwijl de VVD het mogelijk wil maken om winst uit te keren aan investeerders ${ }^{21}$ en ook D66 hier voor lijkt te zijn, ${ }^{22}$ willen het CDA en de ChristenUnie juist een verbod op winstuitkering door ziekenhuizen en zorginstellingen. ${ }^{23}$ De huidige oppositiepartijen in de Tweede Kamer lijken in grote mate voorstander te zijn van het beperken dan wel afschaffen van winstuitkering in de zorg. ${ }^{24}$ Het is van belang om op te merken dat sommige partijen principieel tegen marktwerking in de zorg zijn. ${ }^{25} \mathrm{Zij}$ zullen met voorstellen blijven komen om marktwerking te beperken en het aan banden leggen van winstuitkering is voor hen een belangrijk middel in deze beginselenstrijd.

Daarnaast is winstuitkering door zorgaanbieders niet alleen een discussiepunt in de politiek, het is ook een onderwerp dat volop in beweging is; er spelen 'verschillende wetsvoorstellen en discussies'. ${ }^{26}$ Zo is sinds 2012 een wetsvoorstel aanhangig geweest voor verruiming van winstuitkering van aanbieders van medisch-specialistische zorg. Dit wetsvoorstel is echter op 25 oktober 2019 ingetrokken door de minister. ${ }^{27}$ Daarnaast is thans een wetsvoorstel aanhangig bij de Eerste Kamer om het verbod op winstuitkering door zorgverzekeraars, dat oorspronkelijk voor tien jaar zou gelden, voor onbepaalde tijd te verlengen. ${ }^{28}$ Verder heeft de Eerste Kamer in juni 2020 de Wet toetreding zorgaanbieders

Voor dit artikel is er gekeken naar de standpunten in de partijprogramma's voor de periode 2017-2021. In sommige conceptprogramma's voor de verkiezingen van 2021 zijn kleine veranderingen te vinden. VVD, 'Zeker Nederland. VVD verkiezingsprogramma 2017-2021', p. 65.

22 D66, 'Gereguleerde concurrentie', d66.nl/standpunt-over/gereguleerde-concurrentie/.

23 CDA, 'Keuzes voor een beter Nederland. Verkiezingsprogramma 2017-2021', p. 71; ChristenUnie, 'Marktwerking in de zorg', www.christenunie.nl/standpunt/marktwerking-in-de-zorg.

24 De SP en 50Plus willen bijvoorbeeld geheel af van de marktwerking in de zorg en daarom zijn zij ook geen voorstander van winstuitkering in de zorg, zie www.sp.nl/standpunt/zorgstelselresp.50pluspartij.nl/actueel/ 1660-50plus-zorgstelsel-zorg-thuiszorg-mantelzorg-preventie-standpunten. De PvdA en GroenLinks willen ook geen winstuitkering in de zorg, www.pvda.nl/nieuws/geen-winstuitkering-in-de-zorg/ resp.groenlinks.nl/nieuws/groenlinks-lanceert-voorstel-om-winsten-de-zorg-aan-te-pakken-0. Forum voor Democratie spreekt alleen over 'winstuitkering (...) van verzekeraars [wordt] aan strengere regels gebonden', zie https://www.fvd.nl/zorg. De PVV is net als Forum voor Democratie niet geheel helder over het standpunt. In het verkiezingsprogramma van 2017 staat hier niets over. Wel steunt de PVV in een brief aan de Voorzitter van de Tweede Kamer een voorstel voor een verbod op winstuitkering door verzekeraars, zie www.pvv.nl/84-fj-related/reinette-klever/9417-wetsvoorstel-verbod-winstuitkering-zorgverzekeraars.html. De Partij voor de Dieren is ook niet geheel helder over het standpunt inzake winstuitkering in de zorg. Deze partij laat wel doorschemeren tegen marktwerking te zijn in de zorg, zie www.partijvoordedieren.nl/ standpunten/bezuinigingen-op-de-gezondheidszorg en www.partijvoordedieren.nl/standpunten/ gezondheidszorg.

25 Zie voetnoot 23.

26 Ministerie van Volksgezondheid, Welzijn en Sport, Kamerbrief over winstuitkering door zorgaanbieders, 13 juli 2018, p. 1.

27 Wijziging van de Wet toelating zorginstellingen en enkele andere wetten teneinde investeringsmogelijkheden in medisch-specialistische zorg te bevorderen (Wet vergroten investeringsmogelijkheden in medischspecialistische zorg), brief van de Minister voor Medische Zorg en Sport, Kamerstukken I 2019-20, 33168, P herdruk.

28 Zie Voorstel van wet van de leden Leijten, Bruins Slot en Bouwmeester houdende een verbod op winstuitkering door zorgverzekeraars, Kamerstukken II 2015/16, 34522, nr. 2. 
aangenomen. ${ }^{29}$ Een discussie, aangezwengeld door Keijzer in haar tijd als Tweede Kamerlid, gaat over wintuitkering in de extramurale zorg. Keijzer riep in een motie de regering op om dit te verbieden. ${ }^{30}$ De motie van Keijzer werd door een Kamermeerderheid ondersteund, wat erop duidt dat veel partijen kritisch zijn op winstuitkering in de zorg. ${ }^{31}$ Een aanverwant discussiepunt betreft de bezoldiging van zorgbestuurders. ${ }^{32}$

Al met al is duidelijk dat de verschillende politieke standpunten en de gevoerde discussies over regulering van winstuitkering in de zorg kunnen leiden tot een lappendeken aan regelgeving. Dit is een belangrijk gegeven, waarmee rekening moet worden gehouden bij de toetsing aan met name het EU-recht, zoals hieronder zal blijken.

\section{Reguleren van winst in het licht van het EVRM}

Of een maatregel die winstuitkering door zorginstellingen beperkt EVRM-proof is, is afhankelijk van de vraag of de maatregel al dan niet een schending oplevert van het recht op eigendom in artikel 1 Eerste Protocol (EP) bij het EVRM. Er kan echter alleen sprake zijn van een schending indien winst onder het eigendomsbegrip van artikel 1 EP valt en wanneer de getroffen maatregel een inbreuk inhoudt van dat recht. Daarom staat deze paragraaf eerst stil bij deze twee punten. Overigens beschermt het Handvest van de Grondrechten van de Europese Unie ook het recht op eigendom, in artikel 17, maar zullen wij in deze bijdrage hier niet verder bij stilstaan, omdat kan worden verwacht dat het HvJ EU rekening zal houden met de interpretatie van artikel 1 EP door het EHRM. ${ }^{33}$

Het EHRM interpreteert het eigendomsbegrip autonoom, daarom staat zijn interpretatie los van de betekenis die dit begrip krijgt in het Nederlandse recht. ${ }^{34}$ Zijn interpretatie is niet alleen autonoom, maar ook ruim en omvat niet-fysiek eigendom in de vorm van rechten en belangen, zolang de eigendom een objectief vast te stellen economische waarde vertegenwoordigt. ${ }^{35} \mathrm{Nu}$ winst zo'n waarde vertegenwoordigt, is winst eigendom in de zin van artikel $1 \mathrm{EP}$.

Een inbreuk van het recht op eigendom treedt op wanneer een (rechts)persoon wordt geraakt in het ongestoord genot van zijn eigendom. Onder ongestoord genot valt onder andere het van de hand doen van eigendom. ${ }^{36}$ Wanneer de zorgaanbieders hun winst niet of beperkt mogen uitkeren, dan kunnen zij niet op dezelfde manier ongestoord gebruik

29 Wet van 10 juni 2020, houdende regels in verband met de uitbreiding van het toezicht op nieuwe zorgaanbieders (Wet toetreding zorgaanbieders), (Stb 2020, 180).

30 Kamerstukken II 2016/17, 34522, nr. 15.

31 Dit was weliswaar voordat de verkiezingen in 2017 hadden plaatsgevonden. Dit blijkt ook uit de discussie over winstuitkering door zorgverzekeraars.

32 Brief van de minister voor medische zorg, Kamerstukken II 2017/18, 30111, nr. 105.

33 Art. 52 lid 3 Handvest schrijft namelijk voor dat voor zover het Handvest rechten bevat die corresponderen met de rechten in het EVRM, 'de inhoud en reikwijdte' ervan dezelfde zijn als die het EVRM eraan toekent.

34 EHRM 5 januari 2000, 33202/96 (Beyeler/Italië), ECLI:CE:ECHR:2000:0105JUD003320296, par. 100.

35 EHRM 30 november 2004, 48939/99 (Öneryildiz/Turkije), ECLI:CE:ECHR:2004:1130JUD004893999, par. 124; EHRM 12 juli 2016, 562/05 (SIA AKKA/LAA/Letland), ECLI:CE:ECHR:2016:0712JUD000056205, par. 54.

36 EHRM 13 juni 1979, 6833/74 (Marckx/België), ECLI:CE:ECHR:1979:0613JUD000683374, par. 29. 
maken van hun eigendom als wanneer dat wel toegestaan zou zijn. Er is daarom sprake van een beperking van het recht op eigendom wanneer winstuitkering wordt gereguleerd.

Omdat er een inbreuk optreedt van het recht van zorginstellingen op het ongestoord genot van hun eigendom wanneer er een maatregel wordt getroffen die winstuitkering reguleert, worden nu de drie voorwaarden geschetst die voorkomen dat zo'n maatregel in een schending resulteert. Ten eerste moet de maatregel rusten op een wettelijke grondslag die toegankelijk, voldoende precies en voorzienbaar is. ${ }^{37}$ Omdat het EHRM het begrip wet ook autonoom uitlegt, is een wet in formele zin niet vereist zolang de 'wet' aan de materiele eisen voldoet. ${ }^{38}$ Wanneer de Nederlandse wetgever winst reguleert in een wet die voldoet aan de zojuist genoemde vereisten, is de eerste stap voor EVRM-bestendige regulering van winstuitkering dus gezet.

Ten tweede verlangt het EVRM dat de maatregel een legitiem doel dient in het algemeen belang. ${ }^{39}$ Het EHRM respecteert gewoonlijk het oordeel van de wetgever over het gekozen algemeen belang wanneer de wetgever sociaal en economisch beleid ten uitvoer legt, tenzij het gekozen belang kennelijk onredelijk is. ${ }^{40}$ Een door het EHRM geaccepteerd algemeen belang is bijvoorbeeld de goede organisatie van de gezondheidszorg. ${ }^{41}$ De tweede EVRMhorde voor de Nederlandse wetgever is dus het formuleren van een legitiem doel dat past bij het beperken van de winstuitkering. Zoals in de inleiding van dit artikel is omschreven, bestaan er verschillende redenen om winstuitkering aan banden te leggen. Deze horde zal de wetgever dan ook niet voor problemen plaatsen.

Tot slot moet de maatregel proportioneel zijn in die zin dat er een redelijke verhouding (fair balance) bestaat tussen het betrokken belang en het aangetaste recht van het individu (of de rechtspersoon). ${ }^{42}$ In de context van het recht op eigendom bestaat er geen redelijke verhouding wanneer het individu een individuele en excessieve last moet dragen. ${ }^{43} \mathrm{Om}$ te beoordelen of dit het geval is, zal het EHRM verschillende factoren meewegen. Ten eerste neemt het EHRM mee of het individuele belang niet veel zwaarder wordt getroffen 'dan redelijk is gelet op de doelstellingen van de maatregel'. ${ }^{44}$ Voor deze proportionaliteitstoets stricto sensu is relevant hoe zwaarwegend het belang is ten opzichte van het gewicht van het

37 EHRM 9 november 1999, 26449/95 (Špaček, s.r.o/Tsjechië), ECLI:CE:ECHR:1999:1109JUD002644995, par. 54; EHRM 5 januari 2000, 33202/96 (Beyeler/Italië), ECLI:CE:ECHR:2000:0105JUD003320296, par. 109; Zie voor een voorbeeld van een art. 1 EP-zaak waarin niet aan dit vereiste werd voldaan: EHRM 24 november 2005, 49429/99 (Capital Bank AD/Bulgarije), ECLI:CE:ECHR:2005:1124JUD004942999.

38 EHRM 26 april 1979, 6538/74 (Sunday Times/Verenigd Koninkrijk), ECLI:CE:ECHR:1979:0426JUD000653874, par. 47.

39 Zie art. 1 P1 zelf ('in overeenstemming met het algemeen belang'), maar ook art. 18 EVRM ('Inperking van de toepassing van beperkingen op rechten').

40 EHRM 21 februari 1986, 8793/79 (James e.a./Verenigd Koninkrijk), ECLI:CE:ECHR:1986:0221JUD000879379, par. 46; EHRM 30 juni 2005, 46720/99 (Jahn e.a./Duitsland), ECLI:CE:ECHR:2005:0630JUD004672099, par. 91; EHRM 19 juni 2006, 35014/97 (Hutten-Czapska/Polen), ECLI:CE:ECHR:2006:0619JUD003501497, par. 166; T. Allen, Property and the Human Rights Act 1998, Oxford: Hart Publishing 2005, p. 129-130.

41 EHRM 6 oktober 2005, 11810/03 (Maurice/Frankrijk), ECLI:CE:ECHR:2005:1006JUD001181003, par. 86.

42 EHRM 16 november 2010, 24768/06 (Perdigão/Portugal), ECLI:CE:ECHR:2010:1116JUD002476806, par. 63.

43 EHRM 16 november 2010, 24768/06 (Perdigão/Portugal), ECLI:CE:ECHR:2010:1116JUD002476806, par. 67.

44 J.H. Gerards, EVRM algemene beginselen, Den Haag: Sdu Uitgevers 2011, p. 160. 
aangetaste recht en de mate waarin dat recht wordt beperkt. ${ }^{45}$ Een belang gerelateerd aan de zorg zal waarschijnlijk zwaarder wegen dan het recht van zorginstellingen, ook omdat het EHRM van partijen die een commercieel belang nastreven verwacht dat dat zij risico's kunnen incasseren. ${ }^{46}$ Op grond van deze factor zal het EHRM dus niet snel een schending aannemen vanwege de regulering van winstuitkering door zorgaanbieders. Een andere factor die het EHRM kan meenemen in zijn proportionaliteitsanalyse is of de nationale autoriteiten hebben voorkomen dat de gevolgen van de maatregel willekeurig zijn en of de maatregel op een consistente manier is geïmplementeerd. ${ }^{47}$ Daarnaast kan het EHRM meenemen of de maatregel omgeven is met procedurele waarborgen die mogelijk maken dat de inbreuk kan worden aangevochten. ${ }^{48}$ Om een schending te voorkomen is het, omdat het beperken van de mogelijkheden om winst uit te keren draait om de regulering van eigendom en niet om ontneming, overigens niet in alle gevallen nodig dat compensatie wordt betaald, alhoewel het EHRM dit wel kan meewegen in zijn oordeel. ${ }^{49}$ Het EVRM vereist ten derde en kort gezegd op grond van het proportionaliteitsvereiste van de wetgever dat de maatregel die winstuitkering beperkt niet duidelijk onredelijk is in verschillende opzichten. ${ }^{50}$ Deze niet zo strenge standaard komt ook voort uit het gegeven dat de wetgever veel beoordelingsruimte toekomt bij het bepalen of er een redelijke verhouding bestaat $^{51}$ en bij het kiezen van de maatregel en zijn invulling en reikwijdte. ${ }^{52}$ De beoordelingsruimte betekent dat de wetgever niet per se het minst vergaande of meest geschikte alternatief hoeft te kiezen. ${ }^{53}$

Naar onze mening zijn er voor de toetsing aan het EVMR niet veel problemen te verwachten voor de Nederlandse wetgever. De wetgever moet ervoor zorgen dat de maatregel een wettelijke grondslag heeft die aan bepaalde materiële eisen voldoet en een redelijk legitiem doel dient in het algemeen belang. Tot slot is de maatregel alleen dan proportioneel en

45 EHRM 7 juni 2018, 44460/16 (O'Sullivan McCarthy Mussel Development Ltd/Ierland), ECLI:CE:ECHR: 2018:0607JUD004446016, par. 116.

46 T. Allen, Property and the Human Rights Act 1998, Oxford: Hart Publishing 2005, p. 141. De auteur haalt de volgende zaak aan: EHRM 23 februari 1995, 15375/89 (Gasus Dosier- und Fördertechnik GmbH/Nederland), ECLI:CE:ECHR:1995:0223JUD001537589.

47 EHRM 22 juni 2004, 31443/96 (Broniowski/Polen), ECLI:CE:ECHR:2004:0622JUD003144396, par. 184; EHRM 19 juni 2006, 35014/97 (Hutten-Czapska/Polen), ECLI:CE:ECHR:2006:0619JUD003501497, par. 168.

48 EHRM 21 mei 2002, 28856/95 (Jokela/Finland), ECLI:CE:ECHR:2002:0521JUD002885695, par. 45.

49 EHRM 7 juni 2018, 44460/16 (O'Sullivan McCarthy Mussel Development Ltd/Ierland), ECLI:CE:ECHR: 2018:0607JUD004446016, par. 124. Dit is anders bij de ontneming van eigendom.

50 Zie ter illustratie voor voorbeelden van zaken waarin het EHRM concludeerde dat er wel een schending had plaatsgevonden van art. 1 EP p. 21 van het 'Advies over het reguleren van winstuitkering door zorgaanbieders' als bijlage bij de brief van de Minister van Volksgezondheid, Welzijn en Sport van 9 juli 2019, Kamerstukken II 2018/19, 35000 XVI, nr. 133.

51 EHRM 30 augustus 2007, 44302/02 (J.A. Pye (Oxford) Ltd and J.A. Pye (Oxford) Land Ltd/Verenigd Koninkrijk), ECLI:CE:ECHR:2007:0830JUD004430202, par. 55.

52 EHRM 19 december 1989, 10522/83 (Mellacher e.a./Oostenrijk), ECLI:CE:ECHR:1989:1219JUD001052283, par. 53; EHRM 29 maart 2010, 34044/02 (Depalle/Frankrijk), ECLI:CE:ECHR:2010:0329JUD003404402, par. 87; EHRM 7 juni 2018, 44460/16 (O'Sullivan McCarthy Mussel Development Ltd/Ierland), ECLI:CE:ECHR: 2018:0607JUD004446016, par. 129.

53 EHRM 19 december 1989, 10522/83 (Mellacher e.a./Oostenrijk), ECLI:CE:ECHR:1989:1219JUD001052283, par. 53; EHRM 21 februari 1986, 8793/79 (James e.a./Verenigd Koninkrijk), ECLI:CE:ECHR:1986:0221JUD000879379, par. 51; EHRM 29 maart 2010, 34044/02 (Depalle/Frankrijk), ECLI:CE:ECHR:2010:0329JUD003404402, par. 87. 
daarmee geen schending van het EVRM wanneer hij niet duidelijk onredelijk is in verschillende opzichten.

\section{Reguleren van winstuitkering in het licht van het Unierecht}

Waar het EVRM veel ruimte laat aan de lidstaten om winstuitkering in de zorg geheel te verbieden of nader te reguleren, stelt het Unierecht juist striktere eisen. Regulering van winstuitkering zal getoetst moeten worden aan de regels voor het vrije verkeer uit het Verdrag betreffende de werking van de Europese Unie (VWEU), met name aan de bepalingen over de vrijheid van vestiging, het vrij verkeer van diensten en het vrij verkeer van kapitaal. Verder moet aandacht besteed worden aan de Dienstenrichtlijn. ${ }^{54}$ Aan de ene kant sluit deze richtlijn 'diensten van gezondheidszorg' uit van haar toepassingsbereik. Aan de andere kant kan echter niet uitgesloten worden dat een vorm van winstregulering ook ziet op activiteiten die niet gekwalificeerd kunnen worden als 'diensten van gezondheidszorg' in de zin van deze richtlijn. Hieronder wordt daarom eerst ingegaan op de Verdragsbepalingen voor het vrije verkeer. Daarna komt kort de Dienstenrichtlijn aan de orde.

\subsection{Winstregulering en het vrije verkeer}

De vrijverkeersbepalingen uit het VWEU zijn alleen van toepassing indien er een grensoverschrijdende situatie is. In dat verband neemt het HvJ EU in sommige situaties redelijk snel aan dat er een effect op de handel tussen de lidstaten is. ${ }^{55}$ Dit betekent bijvoorbeeld dat de vrijverkeersbepalingen uit het VWEU toepasbaar zijn wanneer Nederlandse zorginstellingen die aandeelhouders uit andere lidstaten met een beslissende invloed hebben hierop een beroep doen. ${ }^{56}$ Ook dient erop gewezen te worden dat de bepalingen uit het VWEU die specifiek zien op het vrij verkeer van kapitaal niet alleen gelden voor de handel tussen de lidstaten, maar ook voor de handel tussen lidstaten en derde landen. De consequentie hiervan is dat ook zorginstellingen buiten de EU een beroep kunnen doen op deze bepalingen. ${ }^{57}$

De vrijverkeersbepalingen uit het VWEU verbieden alle discriminerende maatregelen en alle overige belemmeringen. Het HvJ EU heeft bij alle vrijverkeersbepalingen gekozen voor een ruime interpretatie van de verbodsbepaling. ${ }^{58}$ Het vrij verkeer van kapitaal, zoals geregeld in artikel 63 VWEU, zal bij regulering van winstuitkering belemmerd worden, aangezien deze maatregel 'ontradend' werkt om te investeren in een zorginstelling. ${ }^{59}$ Investeer-

Richtlijn 2006/123/EG van het Europees Parlement en de Raad van 12 december 2006 betreffende diensten op de interne markt, $\mathrm{Pb} 2006 \mathrm{~L} 376 / 36$.

55 Zie bijvoorbeeld HvJ EU 21 december 2016, C-201/15 (AGET Iraklis), ECLI:EU:C:2016:972. In deze zaak draaide het om regelgeving die de mogelijkheid gaf aan een overheidsorgaan om zich tegen een collectief ontslag te verzetten. Hier gaf het Hvj EU aan dat er een grensoverschrijdend element was, aangezien een aandeelhouder met beslissende invloed uit het buitenland kwam (zie par. 46-47).

56 Zie vorige noot.

57 Zie art. 63 lid 1 VWEU. Hier zijn een aantal uitzonderingen op, zie art. 64 lid 1, 65 lid 4, 66 en 75 VWEU. Deze zijn geen van alle van toepassing bij het reguleren van winstuitkeringen in de zorg.

58 Zie bijv. C. Barnard, The Substantive Law of the EU. The Four Freedoms, Oxford: Oxford University Press 2019, p. 434-464, 472, 533-537 en 554.

59 Zie in dit verband HvJ EU 19 mei 2019, C-531/06 (Commissie/Italië), ECLI:EU:C:2009:315, par. 46. 
ders krijgen immers niet of slechts onder bepaalde omstandigheden dividend uitgekeerd naar aanleiding van hun investeringen. Verder is voor hen de doorverkoop van aandelen minder aantrekkelijk geworden vanwege de beperkingen op de winstuitkering. Nationale regulering van winst ontneemt ondernemingen de mogelijkheid om 'zeer belangrijke bestuursbeslissingen' 60 te nemen en kan 'nadelig werken op de (beurs)waarde van de aandelen van die vennootschap en derhalve op de aantrekkelijkheid om in dergelijke aandelen te investeren'. ${ }^{61}$ Daarnaast wordt de vrijheid van vestiging, zoals bedoeld in artikel 49 VWEU, belemmerd door winstregulering aangezien deze maatregel de toegang tot de markt voor zorginstellingen uit andere lidstaten moeilijker maakt. ${ }^{62}$ Eenzelfde redenering kan uiteraard ook gebruikt worden bij het vrij verkeer van diensten van artikel 56 VWEU: het tijdelijk aanbieden van diensten door een zorginstelling uit een andere lidstaat is gebonden aan restricties betreffende winstuitkering. ${ }^{63}$

Al met al is duidelijk dat het reguleren van winst leidt tot beperkingen van het vrije verkeer. Het zal afhangen van de concrete casuspositie of het vrije verkeer van kapitaal (bijv. een buitenlandse investeerder die wil beleggen in een Nederlandse zorgonderneming), de vrijheid van vestiging (bijv. een zorgonderneming uit een andere lidstaat die een dochteronderneming in Nederland heeft) of het vrije verkeer van diensten (bijv. een zorgonderneming uit een andere lidstaat die op tijdelijke basis patiënten in Nederland behandelt) beperkt wordt. Uiteindelijk zal het bij de vraag naar verenigbaarheid van de regulering van winstuitkering met het Unierecht erom draaien of een dergelijke regulering op basis van excepties gerechtvaardigd kan worden.

Het HvJ EU heeft op basis van de volksgezondheid, welk belang in artikel 52 VWEU gezien wordt als mogelijke reden om beperkingen van het vrije verkeer te rechtvaardigen, erkend dat lidstaten kwaliteit en betaalbaarheid van de zorg als doelstellingen mogen waarborgen. ${ }^{64}$ De in de inleiding genoemde redenen zouden hier dan ook onder geschaard kunnen worden. Daarnaast heeft het HvJ EU erkend dat solidariteitsdoelstellingen en kostenefficiëntie nagestreefd mogen worden door lidstaten. ${ }^{65}$ Deze redenen van solidariteit zijn echter, naar onze mening, lastig te gebruiken als rechtvaardigingsgrond in de Nederlandse praktijk, aangezien solidariteit een veel minder grote rol inneemt in het Nederlandse zorgstelsel dan voorheen, door de vergaande invoering van marktwerking. ${ }^{66}$ Desal-

60 HvJ EU 28 september 2006, C-282/04 en C-283/04 (Commissie/Nederland), ECLI:EU:C:2006:608, par. 24.

61 HvJ EU 28 september 2006, C-282/04 en C-283/04 (Commissie/Nederland), ECLI:EU:C:2006:608, par. 27.

62 Zie bijvoorbeeld HvJ EU 10 maart 2009, C-169/07 (Hartlauer), ECLI:EU:C:2009:141, par. 34-39.

63 Belemmeringen voor het tijdelijk aanbieden van een diensten in een lidstaat vanuit een andere lidstaat wordt gezien als beperking van het vrije verkeer van diensten in de zin van art. 56 VWEU, zo volgt bijv. uit HvJ EU 25 juli 1991, C-76/90 (Säger), ECLI:EU:C:1991:331.

64 Zie HvJ EU 28 januari 2016, C-50/14 (CASTA), ECLI:EU:C:2016:56, par. 61. Zie ook HvJ EU 11 december 2014, C-113/13 (Azienda sanitaria locale n. 5 'Spezzino' e.a.), ECLI:EU:C:2014:2440, par. 57. Vergelijk in dit verband ook E. Plomp, Winst in de zorg. Juridische aspecten van winstuitkering door zorginstellingen, Den Haag: Sdu Uitgevers 2011, p. 291 en 292.

65 HvJ EU 28 januari 2016, C-50/14 (CASTA), ECLI:EU:C:2016:56, par. 63-67; en HvJ EU 11 december 2014, C-113/13 (Azienda sanitaria locale n. 5 'Spezzino’ e.a.), ECLI:EU:C:2014:2440, par. 60-65; HvJ EU 17 juni 1997, C-70/95 (Sodemare e.a.), ECLI:EU:C:1997:301, par. 32-34.

66 Vergelijk in dit verband ook E. Plomp, Winst in de zorg. Juridische aspecten van winstuitkering door zorginstellingen, Den Haag: Sdu Uitgevers 2011, p. 295 en 296. 
niettemin zijn het bewaken van de kwaliteit en het verzekeren van de betaalbaarheid van het Nederlands zorgstelsel legitieme redenen om winstuitkering te reguleren. Uiteindelijk zullen beperkingen van de vrijverkeersbepalingen wel moeten voldoen aan het proportionaliteitsvereiste, met andere woorden: een maatregel moet geschikt zijn om de nagestreefde doelstelling te realiseren (geschiktheid) en het minst belemmerende instrument zijn (noodzakelijkheid). Het zal dan ook van deze proportionaliteitstoets afhangen in hoeverre regulering van winstuitkering door de beugel kan.

Het HvJ EU lijkt de afgelopen jaren de proportionaliteit van een maatregel strenger te zijn gaan toetsen. Een lidstaat moet deugdelijk bewijs aandragen om aan te tonen dat een maatregel geschikt en het minst belemmerend is. Daarnaast moet een lidstaat specifieke gegevens aandragen om het betoog over de toepasselijkheid van de rechtvaardigingsgrond te onderbouwen. ${ }^{67}$ Louter beweringen zijn dan ook onvoldoende om een rechtvaardigingsgrond te onderbouwen. ${ }^{68}$ Wel krijgen lidstaten een beoordelingsmarge van het HvJ EU bij het bepalen van het niveau van bescherming van volksgezondheid en dus bij het maken van regelgeving voor de zorg. ${ }^{69}$

Een andere belangrijke ontwikkeling is dat het HvJ EU in het kader van toetsing aan het proportionaliteitsbeginsel vereist dat maatregelen coherent en systematisch zijn. ${ }^{70}$ Indien dit niet het geval is, wordt de maatregel in kwestie niet geacht geschikt te zijn om de nagestreefde doelstelling te bereiken. Zo werd in de zaak Hartlauer nationale regulering betreffende spreiding van aanbieders van tandheelkundige zorg geacht niet coherent en systematisch te zijn vormgegeven, omdat groepspraktijken van tandartsen niet en tandheelkundige poliklinieken wel onder deze regeling vielen. ${ }^{71}$

Wat betekent het bovenstaande voor de verenigbaarheid van winstregulering met het Unierecht? Onzes inziens moet deze vraag beantwoord worden aan de hand van het vereiste van onderbouwing door middel van specifieke gegevens en het vereiste dat de regulering op coherente en systematische wijze is vormgegeven. Dit brengt ons dan ook tot een aantal aandachtspunten voor de wetgever. Hierbij bespreken wij eerst de motiveringseisen in het licht van een tweetal situaties, namelijk regulering van winstuitkering voor alle zorgaanbieders en een dergelijke regulering voor bepaalde zorgaanbieders. Daarna bespreken

67 Zie bijvoorbeeld HvJ EU 19 oktober 2016, C-148/15 (Deutsche Parkinson Vereinigung), ECLI:EU:C:2016:776, par. 35-36; HvJ EU 23 december 2015, C-333/14 (Scotch Whisky Association), ECLI:EU:C:2015:845, par. 54-56; Hv] EU 27 februari 2020, C-384/18 (Commissie v. België), ECLI:EU:C:2020:124, par. 48 en HvJ EU 26 april 2012, C-456/10 (ANETT), ECLI:EU:C:2012:241, par. 50.

68 Zie de Opinie van A-G Mengozzi, HvJ EU 1 juni 2017, C-125/16 (Malta Dentist Technologists Association e.a.), ECLI:EU:C:2017:421, par. 30, waarnaar het HvJ EU in zijn arrest verwijst: HvJ EU 21 september 2017, C-125/16 (Malta Dentist Technologists Association e.a.), ECLI:EU:C:2017:707, par. 62.

69 HvJ EU 21 september 2017, C-125/16 (Malta Dentist Technologists Association e.a.), ECLI:EU:C:2017:707, par. 60; HvJ EU 19 oktober 2016, C-148/15 (Deutsche Parkinson Vereinigung), ECLI:EU:C:2016:776, par. 30; HvJ EU 28 januari 2016, C-50/14 (CASTA), ECLI:EU:C:2016:56, par. 61 en HvJ EU 11 december 2014, C-113/13 (Azienda sanitaria locale n. 5 'Spezzino' e.a.), ECLI:EU:C:2014:2440, par. 56; HvJ EU 1 juni 2010, C-570/07 en C-571/07 (Blanco Peréz), ECLI:EU:C:2010:300, par. 43 en 44.

70 Zie bijvoorbeeld HvJ EU 10 maart 2019, C-169/07 (Hartlauer), ECLI:EU:C:2009:141, par. 55 en HvJ EU 1 juni 2010, C-570/07 en C-571/07 (Blanco Peréz), ECLI:EU:C:2010:300, par. 94.

71 HvJ EU 10 maart 2019, C-169/07 (Hartlauer), ECLI:EU:C:2009:141. 
we de eisen voor de coherente en systematische vormgeving van regulering van de winstuitkering.

Het vereiste van de onderbouwing aan de hand van specifieke gegevens brengt met zich mee dat de wetgever, indien deze kiest voor het beperken van winstuitkering door alle zorgaanbieders, moet aantonen waarom het noodzakelijk is de regeling van toepassing te maken op alle zorgaanbieders. Het spreekt voor zich dat aan de onderbouwing strengere eisen gesteld worden voor het geval winstuitkering voor alle zorgaanbieders verboden wordt dan voor het geval de regulering niet verder gaat dan het opleggen van bepaalde beperkingen, zoals het slechts toestaan van winstuitkering wanneer een zorgaanbieder voldoende financiële buffers heeft. Hierbij moet er ook aandacht voor bestaan dat het Nederlandse zorgstelsel is gebaseerd op marktwerking, zoals hierboven uiteen is gezet. Op markten wordt gestreefd naar het maken van winst en uitkering daarvan. In het licht hiervan is het van belang aan de hand van specifieke gegevens op overtuigende wijze te onderbouwen waarom desalniettemin de winstuitkering door zorgaanbieders beperkt moet worden. Uiteraard kan bij deze onderbouwing erop gewezen worden dat op grond van artikel 168 lid 7 VWEU de organisatie en verstrekking van gezondheidsdiensten en geneeskundige verzorging tot de bevoegdheden van de lidstaten behoren.

De nationale wetgever zou er daarnaast ook voor kunnen kiezen om de winstuitkering voor bepaalde sectoren in de zorg niet toe te staan. Het lijkt ons evident dat in ieder geval onderbouwd moet worden waarom de problematiek in die sectoren dusdanig is dat winstuitkering beperkt moet worden. Met andere woorden: waarom het beperken van de winstuitkering in die sectoren noodzakelijk is om de kwaliteit en de betaalbaarheid van die zorgdiensten te waarborgen. In Alpine Investments oordeelde het HvJ EU bijvoorbeeld dat een verbod op cold calling ${ }^{72}$ onder meer proportioneel was, aangezien het verbod beperkt [was] tot de markt waarop misbruiken zijn vastgesteld..$^{73}$ De Nederlandse overheid had in die zaak dan ook duidelijk aangetoond dat problemen bestonden in deze specifieke sector.

Het vereiste van coherente en systematische vormgeving brengt met zich dat een maatregel niet geschikt is wanneer op zorgaanbieders die vergelijkbare diensten aanbieden niet dezelfde regels worden toegepast, zoals bleek uit het hierboven besproken arrest Hartlauer. In een andere zaak, Commissie/Italië, ging het om een Italiaans vergunningstelsel voor apotheken, waarbij de vergunning slechts verleend werd wanneer de apotheek geëxploiteerd werd door een apotheker. In de wet waren wel uitzonderingen opgenomen op deze exploitatie-eis. Zo mochten niet-apothekers wel gemeentelijke apotheken exploiteren. Het HvJ EU oordeelde in deze zaak dat gewone apotheken en gemeentelijke apotheken juist niet vergelijkbaar waren, aangezien gemeenten onder meer verregaande controlebevoegdheden hadden voor deze apotheken. Gewone apotheken werden daarentegen geëxploiteerd door commerciële partijen die uiteraard een winstoogmerk hebben en waar geen gemeentelijke controle aanwezig was. ${ }^{74}$ Een en ander wil echter niet zeggen dat bij de uitwerking van winstregulering bepaalde regels niet mogen worden verfijnd. In tegendeel, in de zaak

72 Van cold calling is sprake indien een aanbieder een consument onaangekondigd belt om aan deze bepaalde diensten te verkopen.

73 HvJ EU 10 mei 1995, C-384/93 (Alpine Investments), ECLI:EU:C:1995:126, par. 54.

74 HvJ EU 19 mei 2019, C-531/06 (Commissie t. Italië), ECLI:EU:C:2009:315, par. 74-80. 
Blanco Perez kon de consistentie van een maatregel juist beschermd worden door een verdere differentiatie. ${ }^{75}$ Het ging in deze zaak over de spreiding van apotheken op basis van demografische en geografische gegevens. Het HvJ EU gaf daarbij aan dat in de praktijk in dicht- en in dunbevolkte gebieden eventueel afgeweken moest worden van de spreiding van apotheken op basis van voornoemde criteria, zodat het doel, de toegankelijkheid van deze zorg, niet in gevaar zou komen.

In het kader van de coherente en systematische vormgeving moet de wetgever er ook zorg voor dragen dat er geen lacunes in de wet of in de praktijk voorkomen, waardoor een beperking van de winstuitkering omzeild kan worden. De huidige situatie, waarbij zorginstellingen zorg kunnen uitbesteden aan derden of dochterondernemingen die niet gebonden zijn aan een verbod op winstuitkering, zet de coherente en systematische vormgeving van dit verbod onder druk. De wetgever en de voormalige minister Schippers hebben expliciet erkend dat zorg inderdaad uitbesteed mag worden aan derden en dochterondernemingen niet zijnde zorginstellingen. ${ }^{76}$ Het HvJ EU heeft in het verleden juist meerdere malen geoordeeld dat de lidstaat erop moet toezien dat een omzeiling van de regels niet plaatsvindt. ${ }^{77}$ Lidstaten moeten evidente lacunes in de wet rechtvaardigen. Een duidelijk voorbeeld waar het HvJ EU een wet niet geschikt heeft gevonden doordat er lacunes in te vinden waren, is de zaak Corporación Dermoestética SA. Deze zaak ging om een Italiaanse regeling die reclame voor medisch-chirurgische behandelingen op de nationale televisie verbood. Wel liet de wet de mogelijkheid open om reclame voor dergelijke behandelingen uit te zenden op regionale televisiezenders. Het HvJ EU oordeelde dan ook dat de Italiaanse regeling 'een incoherentie vertoont die de Italiaanse regering niet heeft gepoogd te rechtvaardigen en derhalve niet geschikt is voor het bereiken van het hiervoor genoemde doel dat ermee wordt nagestreefd. ${ }^{78}$ Zoals hierboven is aangegeven, hebben diverse politieke partijen in hun partijprogramma's uiteenlopende standpunten ingenomen over winstuitkering in de zorg. ${ }^{79}$ Naar onze mening zal bij politieke compromissen ervoor gewaakt moeten worden dat de coherentie van een maatregel die winstuitkering beperkt in het geding komt. Voorkomen moet worden dat er een dermate bonte lappendeken aan wetgeving over winstuitkering in de zorg ontstaat dat daardoor de consistentie en daarmee de verenigbaarheid met het Unierecht zwaar onder druk komen te staan.

Hvj EU 1 juni 2010, C-570/07 en C-571/07 (Blanco Peréz), ECLI:EU:C:2010:300, par. 96 en 99-102. Deze redenering werd ook gebruikt in HvJ EU 13 februari 2014, C-367/12 (Sokoll-Seebacher), ECLI:EU:C:2014:68, par. 41-51. Zie ook J.W. van de Gronden, 'De arresten Blanco Pérez en Commissie tegen Spanje: een goed evenwicht tussen de interne markt en de zorgbevoegdheden van de Lidstaten?', NtEr 2010, p. 226.

76 Zie respectievelijk Doorlopende integrale toelichting op artikelen van het voorstel van Wet kwaliteit, klachten en geschillen zorg, Kamerstukken I 2013/14, 32402, F, p. 17; en Antwoord van minister Schippers (VWS) (ontvangen 9 november 2016), Aanhangsel van de Handelingen, Kamerstukken II 2016/17, 449.

77 Zie bijvoorbeeld HvJ EU 28 januari 2016, C-50/14 (CASTA), ECLI:EU:C:2016:56, par. 64 en 65 en HvJ EU 11 december 2014, C-113/13 (Azienda sanitaria locale n. 5 'Spezzino' e.a.), ECLI:EU:C:2014:2440, par. 61 en 62.

78 HvJ EU 17 juli 2008, C-500/06 (Corporación Dermoestética SA), ECLI:EU:C:2008:421, par. 39.

79 Zoals reeds aangegeven is dit gebaseerd op de partijprogramma's voor de periode 2017-2021. In sommige conceptprogramma's voor de verkiezingen van 2021 zijn kleine wijzigingen te vinden. 


\subsection{Dienstenrichtlijn en winstregulering}

Diensten van gezondheidszorg en sociale diensten betreffende sociale huisvesting zijn in artikel 2 lid 2 onder $\mathrm{f}$ resp. j uitgezonderd van de toepasselijkheid van de Dienstenrichtlijn. Bij de eerstgenoemde diensten moet het evenwel gaan om diensten die daadwerkelijk tot doel hebben de gezondheidstoestand van personen te beoordelen, te behouden of te herstellen. ${ }^{80}$ Sociale diensten moeten bestaan uit activiteiten die van wezenlijk belang zijn vanwege het grondrecht op menselijke waardigheid en die een uiting vormen van de beginselen van sociale samenhang en solidariteit. Daarnaast moeten deze activiteiten verstrekt worden door de staat zelf, door een liefdadigheidsinstelling die als zodanig door de staat is erkend of door een particuliere dienstverrichter die daartoe door de staat is gemachtigd ${ }^{81}$ Bepaalde activiteiten die gericht zijn op het ondersteunen van hulpbehoevende personen (en niet op behandeling) kunnen binnen de reikwijdte van de Dienstenrichtlijn vallen, indien deze moeten worden gekwalificeerd als sociale diensten en de verstrekking ervan niet is toevertrouwd aan een particuliere aanbieder die daartoe door de staat is gemachtigd. In geval van harmonisatie van de voorwaarden waaronder bepaalde diensten worden aangeboden, wordt het relevante toetsingskader niet mede gevormd door de VWEU-bepalingen voor het vrije verkeer, maar door de EU-regeling in kwestie (in casu de Dienstenrichtlijn). ${ }^{82}$

Indien winstregulering de vorm zal krijgen van een rechtstreeks geldend voorschrift, valt deze, voor zover het gaat om casusposities betreffende het aanbieden van diensten op permanente basis, onder artikel 15 lid 2 sub b en c Dienstenrichtlijn, waarin nationale eisen voor de rechtsvorm van een dienstverrichter en voor het aandeelhouderschap van een dergelijke verrichter centraal staan..$^{83}$ Dit betekent op grond van artikel 15 lid 3 Dienstenrichtlijn dat nationale winstregulering alleen is toegestaan, indien deze op proportionele wijze een dwingende maatregel van algemeen belang nastreeft. Indien de in te voeren regulering van winstuitkering in de zorg onderdeel wordt van een vergunningstelsel, dan zijn, in casusposities betreffende het aanbieden van diensten op permanente basis, artikel 9 en 10 Dienstenrichtlijn van toepassing. Dit heeft ook als consequentie dat het vergunningenstelsel gerechtvaardigd moet zijn in het licht van een dwingend vereiste van algemeen belang en het proportionaliteitsvereiste. Uit bijvoorbeeld de zaak Hiebler ${ }^{84}$ volgt dat de toetsing aan deze excepties van de Dienstenrichtlijn op vergelijkbare wijze verloopt als bij het vrije verkeer. Dit brengt met zich mee dat overwegingen in verband met bewijs aan de hand van specifieke gegevens alsmede met betrekking tot de coherente en systematische vormgeving een belangrijke rol spelen. Wel moet worden opgemerkt dat uit het arrest Visser Vastgoed ${ }^{85}$ voortvloeit dat artikel 9, 10 en 15 Dienstenrichtlijn niet alleen van toepassing zijn op grensoverschrijdende situaties maar ook op interne situaties (casusposities waarin geen effecten op de tussenstaatse handel aan de orde zijn).

80 Zie Hvj EU 11 juli 2013, C-57/12 (Femarbel), ECLI:EU:C:2013:517, par. 34-41 en considerans 22 van de Dienstenrichtlijn.

81 Zie Hvj EU 11 juli 2013, C-57/12 (Femarbel), ECLI:EU:C:2013:517, par. 44-52 en considerans 27 van de Dienstenrichtlijn.

82 Zie bijv. HvJ EU 5 oktober 1977, 5/77 (Tedeschi), ECLI:EU:C:1977:144.

83 Vergelijk in dit verband ook considerans 71 en 73 van de Dienstenrichtlijn.

84 HvJ EU 23 december 2015, C-293/14 (Hiebler), ECLI:EU:C:2015:843.

85 Gevoegde zaken HvJ EU 30 januari 2018, C-360/15 en C-31/16 (Visser Vastgoed), ECLI:EU:C:2018:44. 
Het is niet uitgesloten dat de regulering van winstuitkering ook zal gelden voor het aanbieden van zorgdiensten op tijdelijke basis in Nederland vanuit een andere lidstaat. In dat geval wordt het relevante toetsingskader gevormd door artikel 16 Dienstenrichtlijn. Op grond van deze bepaling zijn nationale eisen (inclusief die voor winstuitkering) opgelegd aan de zich in een andere lidstaat bevindende verrichter alleen geoorloofd voor zover zij op proportionele wijze de volksgezindheid nastreven. Indien de regulering van winstuitkering onderdeel is van een vergunningstelsel, is het verbod op een vergunningplicht uit artikel 16 lid 2 sub b Dienstenrichtlijn een zeer lastig obstakel. De richtlijn voorziet namelijk niet expliciet in een exceptie voor dit verbod en in de rechtspraak heeft het HvJ EU in het midden gelaten of er desalniettemin toch een beroep op een rechtvaardiging gedaan kan worden. ${ }^{86}$

De toepasselijkheid van de Dienstenrichtlijn kan aanleiding geven tot lastige vraagstukken. Deze toepasselijkheid is alleen aan de orde voor de activiteiten van zorgondernemingen die in het EU-recht als sociale diensten moeten worden gekwalificeerd. De Nederlandse overheid kan echter het aanbieden van deze sociale diensten buiten de reikwijdte van de Dienstenrichtlijn houden, indien zij het aanbieden ervan mandateert aan deze ondernemingen of daartoe een opdracht geeft.

\section{Conclusie}

Het beperken van winstuitkering in de zorg is een heet politiek en maatschappelijk hangijzer. In dit artikel hebben wij uiteengezet in welke omstandigheden het EVRM en het EUrecht invloed kunnen hebben op politieke keuzes om winstuitkering in de zorg te beperken.

Het eigendomsrecht in artikel $1 \mathrm{EP}$ zal naar onze mening weinig tot geen problemen veroorzaken voor de wetgever om winstuitkering in de zorg te reguleren. Het beperken van winstuitkering door bepaalde zorgaanbieders moet niet kennelijk onredelijk zijn. Bij de beoordeling hiervan laat het EHRM veel ruimte aan de verdragsstaten.

Het Unierecht daarentegen stelt striktere eisen, maar zonder dat het onmogelijk wordt om winstuitkering in de zorg te rechtvaardigen. Het HvJ EU geeft lidstaten een beoordelingsmarge bij het bepalen van het niveau van bescherming van de volksgezondheid en dus bij het maken van regelgeving voor de zorg. Vijf aandachtspunten zullen in ogenschouw genomen moeten worden bij het reguleren van winstuitkeringen in de zorg: (i) een eventuele regulering van winstuitkering voor alle zorgaanbieders dient goed onderbouwd te worden, waarbij uiteraard geldt dat de motiveringseisen strikter zijn naarmate de vrijheid van zorgaanbieders verder wordt ingeperkt; (ii) de wetgever moet onderbouwen waarom de beperking van winstuitkering bij specifieke zorgaanbieders noodzakelijk is om de kwaliteit en betaalbaarheid van de zorg te waarborgen; (iii) op zorgaanbieders die vergelijkbare diensten aanbieden moeten dezelfde regels worden toegepast; (iv) misbruik of omzeiling van de regels moet voorkomen worden; (v) de overheid moet overwegen om het aanbieden van diensten die in het EU-recht als sociale diensten worden beschouwd te mandate- 
ren aan particuliere aanbieders dan wel aan hen een opdracht te geven deze diensten te verrichten; zo wordt voorkomen dat de Dienstenrichtlijn van toepassing is.

Het Unierecht en het EVRM laten dus ruimte voor politieke compromissen in dit gevoelige dossier, al zullen irrationele keuzes als onverenigbaar met deze rechtsgebieden aangemerkt kunnen worden. De grote uitdaging waarvoor de wetgever zich gesteld ziet in het licht van uiteenlopende politieke opvattingen, de vele gevoerde debatten en de (financiële) problemen veroorzaakt door de coronacrisis, is om een consistent en deugdelijk onderbouwd regime voor winstuitkering in de zorg vast te stellen. Het is evenwel van essentieel belang dat hij in deze missie slaagt om te voorkomen dat het EU-recht wordt geschonden. 